Revista Iberoamericana. Vol. LXIV, Núms. 182-183, Enero-Junio 1998; 255-270

\title{
REFLEJOS DE LA MÍSTICA DEL SIGLO DE ORO ESPAÑOL EN EL BRASIL MODERNO: UNA LECTURA DE LA POESÍA DE LA MADRE MARIA JOSÉ DE JESUS
}

\author{
POR \\ Miriam Ayres \\ New York University
}

En 1959, tras un período de gran abatimiento, murió sola en un hospital de Río de Janeiro la Madre Maria José de Jesus, religiosa carmelita, poeta y traductora de la obra de Santa Teresa de Ávila al portugués. Años antes, había establecido una rara colaboración literaria con el poeta Manuel Bandeira que le prologó el primer libro de poemas, publicado póstumamente por el Convento de Santa Teresa. Respecto a la monja-poeta escribió Bandeira: "Madre Maria José escrevia versos no mesmo espírito em que os escrevera a grande santa Teresa de Avila" (Andorinha 292). Sin embargo, esta comparación de evidente carácter laudatorio deja que se escape el aspecto quizás más complejo de la producción literaria de la Madre Maria José, es decir, su fidelidad absoluta, y consecuente subordinación, al legado de sus clásicos predecesores españoles Teresa de Ávila y San Juan de la Cruz.

Paradójicamente, la convergencia entre la sensibilidad mística y el talento literario en su poesía contribuyeron para que su presencia pasara inadvertida en el reducido círculo de poetas brasileños dedicados a la poesía religiosa. Las razones de su virtual desaparecimiento son posiblemente dos. Primero, su poesía - claramente vinculada a la poética de base espiritual de sus clásicos predecesores, Santa Teresa y San Juanrefleja el problema de la diseminación tardía en Brasil de la escritura mística de la España del Siglo de Oro. Y segundo, su rol de traductora - una tarea que Walter Benjamin califica de "derivative, ultimate and ideational" (77)— quizás haya contribuido de algún modo para que se obliterara su perfil de autora.

La escritura mística ha sido tradicionalmente objeto de constante escrutinio, en parte por brindarnos textos de sentido opaco, productos de una rara amalgama entre el impulso religioso y la dicción poética. El discurso místico, que desafia los límites comunicativos del lenguaje para expresar la experiencia profundamente internalizada de lo divino, se forja a través de alusiones, sorprendentes asociaciones y vastas redes metafóricas; por lo tanto, converge en muchos aspectos con las formas narrativas del discurso literario propiamente dicho. William James parece haber sido uno de los primeros pensadores en reevaluar los contenidos estrictamente devocionales de la literatura religiosa. En su clásico estudio sobre el misticismo, James calificaría la prosa 
de Santa Teresa y la poesía de San Juan como "altas" manifestaciones del arte literario, comparando su estructura con la de la música. También Paul Valéry, algunos años después, reflexionando sobre el tema que le obsesionaba -los procesos mismos de creación y evolución de la poesía - detectaría en la narrativa espiritual del catolicismo occidental formas de expresión "no-conceptuales", para él la base discursiva de la poesía.

A Valéry se le debe incluir en el planteo de las relaciones entre misticismo y arte poético por dos motivos aparentemente sin conexión: sus frecuentes afirmaciones de agnosticismo y su riguroso programa estético. Aunque se haya identificado como noreligioso, el poeta, lector de James (Robinson-Valéry 16), parece haber aceptado las ideas del filósofo sobre el valor literario de la escritura mística cuando desarrolló la noción, que jamás abandonaría, de que la literatura es "une mystique de développement interne" (Robinson-Valéry 23). Así es que en Valéry la interiorización, base de las prácticas meditativas de la espiritualidad mística, es un ejercicio de perfeccionamiento de la sensibilidad y de la percepción - valores fundamentales para el desarrollo del arte poético.

Sin embargo, en estas reflexiones, el poeta que se autodescribió como aquél que "pense en rationaliste archi-pur [y que] sens en mistique" (Valéry, Cahiers 418), se refería a la base fenomenológica del misticismo, más que a sus formas discursivas, hasta que, en un momento dado, y por casualidad casi mística, descubrió la poesía de San Juan de la Cruz. El encuentro entre el esteta francés y el místico español se efectuó gracias a las traducciones de "Cántico espiritual" y de "Noche oscura" hechas por un desconocido monje carmelita francés del siglo XVII. La reacción de Valéry al leerlas fue de pura sorpresa. San Juan lo había conquistado por la precisión de sus imágenes y por la musicalidad de sus versos (The Art of Poetry 284). Pero sobre todo, Valéry se dejaría cautivar por su traductor, el Padre Ciprián.

Figura casi enteramente ignorada, el monje impresionó a Valéry por haber mantenido en francés la pureza de la poesía de San Juan y por haber renunciado al papel de autor. Al autor francés - viviendo en una época en que "almost the only thing of importance is to become known"-(The Art of Poetry 289) le conmoverían entonces la "curiosa invisibilidad"(289) y dedicación con que el religioso carmelita llegó a darle a San Juan una voz en francés. Al descubrir la poesía de San Juan, Valéry recuperaría del olvido a su traductor y, a partir de ahí, basado en su propia experiencia, se propondría reflexionar sobre la difícil posición a que el público y la crítica habían relegado la poesía religiosa.

Curiosamente este proceso de recuperación de un género literario en riesgo de olvido se repetiría en Brasil en los años cincuenta, cuando Manuel Bandeira, al igual que Valéry, se dedicó a la tarea de promover la desconocida obra de la Madre Maria José. Bandeira y la madre desarrollaron una curiosa amistad intelectual sin jamás haberse visto, pues la monja observaba la regla carmelita de reclusión estándole vedado establecer contactos cara a cara con personas que no fueran las religiosas. La prima de 
Bandeira, monja en el mismo convento, le pidió al poeta que se reuniera con la priora, en aquel entonces la Madre Maria José, para aconsejarla sobre dificultades que enfrentaba en su traducción de Santa Teresa. Pronto, lo que sería en principio sólo una cita evolucionó en colaboración literaria. A la madre, Bandeira le enseñó la "técnica do verso livre que ela teve curiosidade de conhecer" (Bandeira, Andorinha 290). Juntos trabajaron en la composición de una pieza de oratorio titulada "Alegrias de Nossa Senhora". Su admiración por el talento de la monja llevó al infatigable poeta modernista, a pesar de su declarado agnosticismo, a reunir argumentos que le permitiesen reflexionar sobre el estado de profundo abandono al cual se había relegado la poesía de inspiración religiosa y, además, se hizo un ardiente defensor del género.

Bandeira, que en muchos aspectos participa de las ideas de Valéry — particularmente en el considerar la poesía como la más perfecta forma del arte literario- - poseía, al contrario del poeta francés, una suerte de personalidad artística proteica. Su trayectoria poética se distingue por cambios en la temática, la línea estética o los modos de composición aparentemente bruscos, aunque cuidadosamente concebidos. El carácter experimental de Bandeira claramente choca con el rigor casi clásico de Valéry, pero ambos llegaron, a través de distintas trayectorias, a conclusiones análogas respecto al valor de la cultura espiritual expresada en poesía. De algún modo, reconocieron también las intersecciones posibles entre la poesía moderna y la lírica de inspiración religiosa.

Valéry y Bandeira, como poetas y críticos, encontraron en el Siglo de Oro español y en las figuras oscuras de dos religiosos y traductores materia de reflexión sobre la naturaleza misma del proceso de renovación de la poesía. Fueron, además, los dos religiosos los que presentaron al francés y al brasileño la mística española clásica en sus traducciones y que dieron continuidad al arte consagrado por esta tradición. Pero el hecho de que tales traducciones hayan de algún modo desaparecido de la memoria literaria actual, ilustra la presencia de una singular dinámica de transmisión de valores en el campo de la literatura de base religiosa: la de que ilustres precursores como Teresa de Ávila y San Juan de la Cruz se hayan convertido en monumentos, y que, sus continuadores (en Francia el Padre Ciprián, y en Brasil la Madre MariaJosé), hayan elegido únicamente preservarlos o enaltecerlos en sus obras. Fieles seguidores de la ética carmelita de la humildad, los dos religiosos prefirieron hacerse "invisibles" para el universo quizás demasiado mundano de las instituciones literarias. Las implicaciones y el efecto de tal decisión en la poesía de la Madre Maria José es el tema central del análisis que se sigue.

La orden carmelita, fundada por Teresa de Ávila en el siglo XVI, sólo llegó a Brasil dos décadas después y bajo circunstancias adversas. Por un lado su fundadora - la beata Jacinta de São José - tuvo que enfrentarse sucesivas veces con el obispo de Río de Janeiro, quien, fiel a la decisión de la corona portuguesa de limitar la expansión de las órdenes religiosas en el imperio, la acusaba de promover y practicar "excesos místicos" (Algranti 96). Por otro lado, Portugal, en su esfuerzo de aumentar la 
población de su colonia en América, a la vez que buscaba "emblanquecerla," trató de impedir que se fomentara el celibato, especialmente entre las pocas mujeres blancas residentes en Brasil (64). A pesar de los obstáculos, se estableció por fin la orden carmelita en 1781, pero es preciso decir que el convento de Santa Teresa se mantuvo por largos años alejado de su base ibérica, sin prácticamente recibir ningún apoyo de su liderazgo español o portugués. Asimismo, aunque la fundadora de la orden hubiera introducido en Río de Janeiro libros sobre la espiritualidad mística junto con las obras de Teresa de Ávila y San Juan, no sería sino hasta las primeras décadas de este siglo, en manos de la Madre José, que la cultura religiosa y literaria de la tradición carmelita se daría a conocer más ampliamente en Brasil.

Nacida en Río de Janeiro a finales del siglo XIX, la Madre Maria José dedicó los últimos 23 años de su vida a la traducción al portugués de la obra completa de Santa Teresa. A través de su ardua labor de traductora se convirtió en una suerte de eco de la monja española, y al hacerlo se dejó absorber en la absoluta singularidad de la figura y legados de su famosa predecesora.

Pese a ser huérfanas - tanto Teresa de Ávila como Honorina de Abreu (nombre secular de la Madre Maria José), y de haber rogado las dos a la Virgen Maria que reemplazara a sus respectivas madres - pocas son las coincidencias entre la vida de la monja brasileña y la que nos narrara Santa Teresa en su autobiografia. A diferencia de la carmelita española que proviene de la nobleza decadente, la Madre Maria José pertenecía a la élite intelectual de Río de Janeiro. Extremadamente bien educada y con especial talento para los idiomas, contaba el latín -lengua que Santa Teresa lamentaba jamás haber manejado- entre los otros seis idiomas que escribía o hablaba. Mientras que a Santa Teresa le tomó casi dos años decidirse a ingresar a la orden carmelita, la Madre Maria José, según algunos relatos, abandonó abruptamente la vida secular después de una noche de gala, luego de haber tenido lo que fue su primera experiencia mística (Sciadini 26). La decisión de Honorina trastornó a su padre, el distinguido historiador Capistrano de Abreu, que mucho se enorgullecía de la educación neoiluminista y afrancesada de su hija. Por eso, al contrario del padre de Teresa, que apoyó su elección de la vida religiosa, Abreu se negó a ver de nuevo a Honorina después de su entrada en el convento de las carmelitas en 1911. La ruptura con el padre y la imposibilidad de reconciliar el radical ateísmo de éste con la vida religiosa que para sí eligió constituyeron parte del drama religioso de la Madre Maria José.

Un año después de hacerse monja volvió a escribir poesía - actividad que había abandonado al decidirse por la vida religiosa. Pero su regreso a la literatura fue sobre todo un gesto de obediencia. Pues, repitiendo una honorable tradición de la cultura literaria conventual (Leclercq 196), sólo recomenzó a escribir atendiendo al insistente pedido de la priora de su convento. La Madre Maria José desempeñaba anónimamente las tareas de traducción o escritura que le eran asignadas en cumplimento de la tradición de reserva y modestia vigente en la vida conventual. En poco tiempo se hizo claro que ella era la mejor formada de las monjas de su comunidad, y se decidió que sus talentos 
y dotes intelectuales se aplicarían al servicio de la orden carmelita entonces floreciente en el sureste de Brasil.

Es preciso decir que el brillo de la Madre Maria José es raro en la historia conventual brasileña. Las instituciones religiosas del país, desde su fundación, se enfrentaron continuamente con graves dificultades económicas. Así, la lucha por la mera supervivencia se reflejaba en el nivel de educación de las religiosas, casi siempre precario. La mayoría de las mujeres religiosas brasileñas, incluyendo a las de origen aristocrático, carecían de una educación sistemática, habiendo sido típicamente autodidactas o recibido escasa educación en sus hogares (Algranti 248). A diferencia de la situación en Hispanoamérica, las instituciones religiosas femeninas en el Brasil colonial nunca llegaron a constituirse en centros de espiritualidad mística o refugio para mujeres cultas, como Sor Juana Inés de la Cruz. Mientras en México los conventos funcionaron como instituciones educacionales desde el siglo XVI, en Brasil eso no ocurriría hasta fines del siglo XVIII. La tradición de escribir —una de las más estimadas prácticas carmelitas en la península Ibérica e Hispanoamérica-era entonces rara, si no virtualmente inexistente, en Brasil (248). Se puede entonces concluir que el trabajo de la Madre Maria José marca el inicio de una cultura literaria en los conventos brasileños, gracias en particular a sus traducciones y su a obra poética.

En sus diferentes formas, la poesía de la Madre Maria José comunica un cierto triunfalismo religioso, que a nivel histórico y sociológico indica la posición de autoridad que empezó a conquistar el catolicismo institucional en Brasil a comienzos de siglo (Romano 111). A nivel lingüístico, sus poemas, en vez de centrarse en imágenes y metáforas densas — como suele ocurrir en el lenguaje místico de San Juan - se valen de comparaciones directas muy al modo de la prosa teresiana. A pesar de esos rasgos, la Madre Maria José sigue el modelo de San Juan, en particular al atenerse a esquemas métricos estrictos y al elegir formas poéticas basadas en paradigmas musicales. En verdad, el hecho de que su poesía valorice patrones estables de rima y armonía de ritmo, le facultó a componer letras de himnos religiosos. Además de los himnos y cantos que compuso para que fueran ejecutados en las fiestas religiosas de su comunidad, escribió innumerables sonetos que fueron, quizás, su medio predilecto de expresión.

Uno de estos sonetos conlleva su muy particular versión - por ser optimista — de la doctrina medieval cristiana de contemptu mundi, persistente en la ortodoxia carmelita. ${ }^{1}$ En el mismo soneto se destacan aún resonancias del culto a la naturaleza,

\footnotetext{
${ }^{1}$ Seguimos aquí la interpretación de la teología cristiana en la Edad Media y el Renacimiento del historiador francés Jean Delumeau. Según él, la doctrina de contemptu mundi constituye un sistema de valores negativos que rechaza nociones de "sujeto," "individuo" e "identidad". Expresa entonces una tradición de desprecio por el orden mundano, presente en la Biblia y en filósofos moralistas clásicos como Plutarco. Delumeau explica que tal doctrina proviene de "a lasting nostalgia for a primitive, asexual man-angel, 'spiritualized' and dedicated to pure contemplation". A este "hombre angélico" se le puede ver como el modelo de otra figura paradigmática del cristianismo radical de la Edad Media y la Contrarreforma, "el héroe cristiano" (9-12).
} 
muy presente también en la lírica de San Juan, aparte de la repetición del clásico tema teresiano de la "interioridad de lo divino" - noción que Santa Teresa heredó de San Agustín y cuyo postulado es el de que Dios se descubre a través de un ascético proceso de profundización de la vida interior. Sin embargo, en contraste con el tono característicamente alusivo de San Juan y con las densas formas retóricas teresianas, el soneto de la Madre Maria José echa mano de un estilo simple, figurativo, y por lo tanto más literal. A nivel temático, el poema pone de manifiesto un claro mensaje redentor.

Se puede por consiguiente inferir que la base de la poética de la Madre Maria José está en una suerte de motivación estética vinculada a una concepción categórica de la fe. A este respecto, escribe la monja brasileña:

Olhei tudo ao redor, e estranhei a existencia ...

Quer quer dizer a vida? É sonho? É realidade?

Meu ser, o espaço, o tempo, o mundo, a humanidade

O que vejo, o que penso -é ficção ou evidência?

Pareceu-me o universo uma enorme falência,

E eu o átomo errante e só na imensidade...

Por tôda a parte o vácuo, a falta, a soledade,

E, sibilando no ar, um sôpro de demência...

Vi-me só, num penhasco, e o mar já me tragava

Então bradei: "Meu Deus! eu creio! a ti acudo

És o Princípio e o Fim; e eu tua filha e escrava..."

E logo a luz voltou... A terra vi florida,

Olhei tudo em redor, e reconheci tudo ...

E prossegui, serena, a jornada da vida.

("Vertigem" Sonetos 37)

Se nos presenta aquí una visión de mundo que desde luego refleja dicotomías elementales típicas de la espiritualidad teresiana, que esquemáticamente define al mundo físico como maligno y peligroso, $y$ al mundo espiritual como puro y estable. Sólo que, a modo de variación de la teología negativa teresiana, la carmelita brasileña expresa su "rechazo al mundo" y a lo mundano en formas discretas y moderadas en tono. Por eso, en vez de condenar a las demoníacas trampas del mundo físico - tema constante en el ideario y en la retórica de la Contrarreforma - la Madre Maria José resalta las marcas negativas de un mundo en el cual Dios se ha constituido en ausencia. Para ello utiliza pares antitéticos, como, por ejemplo, caos (condensado en las imágenes de la naturaleza amenazadora y de la mente desordenada) y equilibrio (que se alcanza únicamente por medio de la interiorización o el autoexamen, que culminan 
en una suerte de autoimpuesta epifanía, es decir, en la evidencia de que la aspiración a lo divino es el fruto de un drama sobre todo íntimo). Sin embargo, en el poema Dios figura menos como entidad religiosa que como categoría filosófica abstracta. Por eso, el rol epistemológico de Dios, respecto a la voz evocativa del soneto es el de permitirle constituir un nuevo "yo", vinculado al orden divino a través de nexos relacionales contradictorios. Al representarse los vínculos entre individuo y Dios, la poeta utiliza entonces imágenes que expresan, o bien relaciones de parentesco (sou sua filha), o bien relaciones de propiedad y subordinación (sou sua escrava).

Ahora bien, la trilogía de sonetos titulada "Fé", "Esperança" y "Caridade," aunque claramente glosa tres lemas fundacionales de la dogmática cristiana, tiene un tono inesperadamente personal. Si se los toma en conjunto, los sonetos de la Madre Maria José tienden a manifestar dos ejes temáticos algo contrastantes. Por un lado, se constituyen en exhortaciones u homenajes a figuras ejemplares; por otro, narran el drama religioso de un cierto sujeto lírico, que no puede ser reducido a una construcción poética pura. En dicha trilogía se halla, por lo tanto, bien marcada una voz que a la vez dirige a la enunciación y le imparte un tono claramente autobiográfico. Siguiendo el molde del relato confesional de Santa Teresa en La vida, estos sonetos se componen de fragmentos autobiográficos que le sirven a la Madre Maria José como pruebas documentales de los varios estadios de su evolución espiritual.

La mayor diferencia entre los sujetos de la narración, en la carmelita brasileña y en la española, reside en el modo como se comunican valores teológicos fundamentales, como la profesión de fe y la experiencia de la conversión. En vez de utilizar la retórica de la vacilación, del miedo al equívoco o de la auto-acusación, características de Santa Teresa, la Madre Maria José elige moldear su dicción poética en tonos predominantemente afirmativos. El concepto de fe, con sus implicaciones positivas, se hace entonces el centro irradiador de su poética, y el término "fe" - además de expresar la pre-condición para que el ser religioso acepte la regla divina en su vidafigura también como metonimia de la presencia de lo divino. Así es que el elemento fe es glorificado en su poesía a través de la personificación del concepto y de su repetida alegorización. En su configuración lírica, la celebración de la fe se realiza por medio de vocativos similares a los que se emplean en las odas y los panegíricos. Tenemos pues versos como el siguiente:

$\mathrm{O}$ Fe, tu fôste a Mãe que, na piscina

Batismal, me adotaste com clemência;

Que me descortinaste - inda eu menina-

Horizontes sem fim à inteligência.

Mil vêzes arrancaste-me à sentina

Do pecado e tornaste-me à inocência;

Em meus lábios puseste a Hóstia Divina

Que iluminou e encheu minha existência. 
Tu farás com que eu receba num sorriso A morte ... E - salva enfim de mil escolhosTu me guiarás às portas do Paraíso.

E então — como uma luz que se apagasse-

Terás fim, quando eu com meus próprios olhos Fitar o Sol Divino face a face ...

("Fe" Sonetos 25)

En este soneto la poeta aprovecha el sistema de las relaciones de parentesco como red metafórica que instaura un orden jerárquico entre ella misma y valores espirituales abstractos. Igualmente la traumática orfandad de la Madre Maria José se proyecta en instancias en las que ella se presenta como "hermana" o "hija" que ruega a los destinatarios de su invocación poética que le sirvan de madre o padre. Al trabar relaciones de parentesco con figuras clásicas del mundo religioso, la Madre Maria José crea, a nivel temático, zonas de familiarización con lo sagrado repitiendo así la afirmación de Santa Teresa de que lo divino se prefigura en los hechos sencillos de la vida (Peers 97). ${ }^{2}$ Por otra parte, en la Madre Maria José, estos temas claramente elementales se enuncian por medio de un rigoroso sistema estrófico y de la métrica convencional. Tal control de la estructura lírica sugiere tanto el deseo de reordenar su experiencia interior, como pone de manifiesto su clara afinidad con el proyecto poético del Parnasianismo. ${ }^{3}$

\footnotetext{
${ }^{2}$ Aunque aquí se use la biografia de la Madre Maria José como forma de explicar la reiteración en su escritura de tratamientos líricos de las relaciones de parentesco, otra interpretación de tal práctica se puede extraer del concepto weberiano de "fraternidad religiosa" [religious brotherliness]-la adopción de lazos familiares simbólicos entre individuos que pertenecen a una comunidad religiosa dada. La visión weberiana de la ética de la fraternidad como mecanismo que ofrece "protection against symbolic incest" es fundamental para que se comprendan aspectos eróticos del discurso místico. Weber considera que en vez de expresar un erotismo que le es inherente, el discurso místico, en verdad, simplemente basa su gramática en los elementos que componen la esfera erótica, ya que, como afirma el sociólogo alemán, lo erótico es proscripto de la cultura religiosa, por considerárselo "enemigo del asceticismo" (Weber, The Sociology 237).

${ }^{3}$ El Parnasianismo brasileño empezó a darse a conocer hacia fines del siglo XIX y mantuvo su robustez hasta por lo menos las dos primeras décadas de este siglo. Su paladín, el poeta Olavo Bilac, introdujo las ideas de Theóphile Gautier en Brasil y lideró una intensa cruzada en defensa del rigorismo formal en la poesía. Sin embargo, la hegemonía del parnasianismo terminó por llevar a la poesía brasileña al estancamiento, culminando en una cierta vulgarización del arte poético. Los poetas de la vanguardia brasileña, o sea los modernistas, rechazaron sistemáticamente esta tendencia en los años veinte. El poeta Manuel Bandeira, quien mantuvo una circunstancial asociación con el grupo modernista, fue uno de los mayores admiradores de la Madre María José, y le aconsejó librarse de los excesos del formalismo, al iniciarla en la técnica vanguardista de la composición en verso libre.
} 
Al igual que para San Juan de la Cruz, el misticismo fue para la Madre Maria José un elemento que sólo esporádicamente forma parte de su vida literaria. Uno de los únicos episodios de contenido místico que llegó a reportar ocurrió en 1940, mientras convalecía de una larga enfermedad. En el huerto del convento, junto a la enfermería donde reposaba, la monja vio un gran pájaro con rasgos de pelícano, e inmediatamente lo asoció a la figura del espíritu santo. Más tarde, ella compuso un relato en prosa poética describiendo el evento, e incluyendo en su tratamiento imágenes que aluden a la unión mística (Vôo para Deus 44). El poema, titulado "Ao divino pelicano," marca la iniciación de la Madre Maria José en la práctica del verso libre - forma que más tarde pasó a utilizar en piezas largas y discursivas (Bandeira, "Prefacio" 13). "Ao divino pelicano" es un himno devocional en el que se funden modalidades retóricas complementarias, como las de la súplica y del panegírico.

Moldeado por imágenes que denotan sometimiento y fusión, cuando por ejemplo se dirige a Jesús con invocaciones en tono ritualístico ("[d]eixa-me beber teu sangue", "mergulha-me em ti", "purifica-me", "[p]enetra-me com teu perfume") el poema presenta diferentes instancias de hibridización y entrelazamiento del orden humano y sagrado. Pero, paradójica y simultáneamente, se dramatiza en el texto el deseo permanente de alcanzar la unión que se acaba de lograr. De ahí que el poema exhiba la tensión permanente entre, por un lado, expresiones de anhelo, $\mathrm{y}$, por otro, la ansiedad de perder lo que no se cree haber conquistado.

En muchos aspectos, la poesía de la Madre Maria José se sitúa en el marco de la literatura monástica medieval. Jean Leclercq nos explica que dicha literatura se caracteriza sobre todo por la extrema estabilidad de sus géneros, guardando los monjesescritores una reverencial fidelidad a sus modelos, es decir, las obras de los Padres de la Iglesia y los clásicos. Otra característica de esta tradición es la simplicidad de sus temas y estilo. A este respecto, afirma Leclercq que "monastic literature always retains [...] the same absence of complexity. Its motto remains sancta simplicitas" (190).

La obra de la Madre Maria José, igual que su vida, se dejó regular por el rígido ascetismo carmelita, constituyéndose predominantemente de temas limitados y formas poéticas estables. En el acto mismo de escribir, la monja brasileña también procedió con estricta economía. Se negaba a desperdiciar papel y, en vez de cuadernos, usaba sobras de papel blanco o pedacitos de papel de envolver. En las largas horas que pasaba escribiendo se sentaba en el suelo de su celda, usando como escritorio una pequeña tabla de madera (Sciadini 151). Su austera rutina de trabajo era la prueba de que se preservaba en su comunidad la ascética tradición devocional establecida por Santa Teresa.

Como suelen hacer algunos místicos y escritores de inspiración religiosa, la Madre Maria José buscó despersonalizar su producción literaria, rechazando cabalmente la idea de propiedad intelectual subyacente a la condición de autor. Al hacerlo terminó por "desposeer" sus propios textos. Su negligencia intencional en reunir u ordenar a sus manuscritos llevó a que muchos de ellos se perdieran, fueron tirados o rasgados (Sciadini 51). En la escritura de edificación espiritual que produjo, la Madre Maria 
José, al modo de los monjes medievales, parece haber buscado "to construct the Church, the body of Christ" (Leclercq 194).

La poeta siguió, tanto a nivel doctrinal como retórico, el precepto carmelita de la "humildad," a cuya defensa Santa Teresa se dedicó en sus primeros escritos. Específicamente la idea de la humildad se presenta en sus textos al modo de tropo o elemento poético que al fin contribuye para que la voz lírica se debilite, exaltando con ello a sus clásicos precursores españoles. Dedica a Santa Teresa un himno -en celebración al 15 de octubre, día de la santa patrona de España-compuesto en cuartetos endecasílabos precisos. Algunas de sus más significativas estrofas son sobremanera laudatorias, como por ejemplo,

Jóia da Espanha, glória do Carmelo

Santa Madre, seráfica Teresa,

Sempre foi nesta vida vosso anelo

A glória do Senhor, sua grandeza.

Entre Vós e Jesus houve porfia,

Luta de amor e generosidade:

Vosso coração nobre respondia

A cada dom com nova caridade.

Mas, enfim, cara Mãe, fôste vencida ...

Quem supera de um Deus a Onipotência?

Da mão de um Serafim caís ferida

No mar perdida da Divina Essência.

$\mathrm{Ah}$ ! foi que Deus vos conservou cativa

Do corpo, enquanto fôste necessária,

- Sempre morta de amor e sempre viva-

Suspirando qual rôla solitária.

O’ seráfica pomba prisioneira,

Santa Madre Teresa, níveo lírio,

$\mathrm{Oh}$ ! como voais a vosso Deus ligeira

Do amor levando a palma do martírio!

Dai-nos o amor, o zêlo, a penitência,

A oração que quereis das Carmelitas

$\mathrm{Na}$ estrada da humildade e da obediência

Guiai-nos, ó Mãe, com vossas mãos benditas.

("Na festa de nossa Santa Madre Teresa", Festas do Carmelo 78-80)

Dicha pieza, que encierra en unas pocas estrofas instancias claves de la hagiología de Santa Teresa, tiene como propósito recalcar los signos de su leyenda y así inscribir 
a la santa española en el orden de lo sagrado. Para eso, la Madre Maria José aprovecha la escena de la transverberación como momento en que se dramatiza una sagrada batalla cuya conclusión es la "pérdida"o inclusión de Teresa en la esencia divina. ${ }^{4}$ Calificada de "jóia de Espanha," el lado humano de la santa patrona de ese país queda sólo muy brevemente delineado (estrofa 4). La naturaleza humana de Teresa se configura entonces en imágenes de tono melancólico como la "rola solitaria, cativa do corpo suspirando," alusiva a los obstáculos que el cuerpo físico impone a la búsqueda de la transcendencia. El resto del poema subraya los atributos sagrados de Santa Teresa.

La figura de la santa emerge como una suerte de deidad, a la que se glorifica a través de referencias a los símbolos que forman su leyenda: la "palma" de la virginidad; el lirio blanco de la pureza espiritual; el "serafín" de la escena de la transverberación. Irónicamente, en la obra de la Madre Maria José la amplificación del culto a Santa Teresa parece indicarnos una peculiar inversión de papeles. Así como la ilustre española homenajeó en su autobiografía a héroes de la tradición católica como San Agustín, la monja brasileña, a su vez, reverencia a Teresa, adoptando para sí una voz de autodesprecio que es típica de la santa. Este proceso de sumisión se puede analizar a partir del concepto weberiano de "retribución de gracias" (Weber, The Sociology 162). ${ }^{5}$ En la Madre Maria José esta economía retributiva se procesa a través del intercambio de valores espirituales; es decir, sus votos de humildad y subordinación en realidad contienen un elemento de autoexaltación, puesto que marcan una relación de equivalencia entre ella y Santa Teresa.

La poeta dedicó también a San Juan un poema: un himno en estrofas de ocho versos titulado "Canto de nosso pai São João da Cruz," en el cual el ritmo es el elemento fundamental. La canción empieza con un estribillo de carácter encomiástico y luego cambia a una serie de estrofas de tono suplicante. En ellas se repite la dinámica del sistema de "retribución de gracias," en el que el sujeto de la enunciación se desvalora al compararse con la figura del legendario santo y poeta:

\author{
Meu pai querido \\ São João da Cruz, \\ $\mathrm{O}^{\prime}$ terno amante de Jesus \\ De meu Jesus: \\ Dize-me, ensina-me \\ O que é amar \\ E pelo Amado \\ Tudo imolar.
}

\footnotetext{
${ }^{4}$ La trasverberación es el famoso pasaje de La vida, eternizado en la escultura de Bernini, en que la mística española es herida por el dardo de un querubín que le traspasa el corazón. Esta escena es generalmente vista como cargada de sentido erótico.

${ }^{5}$ Se advierte la dinámica de este proceso en la perplejidad de Santa Teresa hacía San Pedro de Alcántara y en la fascinación de San Juan por los patriarcas y mártires de la Iglesia. En esos casos el esquema "retributivo" de Weber muestra que el poder espiritual se concede sólo a aquéllos que aceptan subordinarse a la autoridad de figuras canónicas indiscutibles.
} 
Fôste na terra

Louco de amor

Faze-me louca

De igual ardor:

$O$ fogo em que ardes

Qual Serafim,

Venha a meu peito,

Se ateie em mim.

Vê tua filha

Quer-te imitar,

Mas, miserável,

Só faz pecar;

Pai meu, sustem-me

Pra eu não cair,

E teus exemplos

Sempre seguir.

Quero ser santa,

Mas quem sou eu?

Vem ajudar-me.

$\mathrm{Tu}$, Padre meu.

Neste Carmelo

Possa eu viver,

E santamente

Nêle morrer.

(Festa do Carmelo 95-8)

Tal vez porque en sus escritos San Juan trate de sistematizar la experiencia mística, minimizando los aspectos más inmediatamente sobrenaturales, la monja lo representa en tonos menos efusivos que los utilizados al celebrar a Santa Teresa. Las pocas hipérboles del himno se concentran en torno a la simbología del "fuego", elemento fundamental en la "Llama de amor vivo" (San Juan de la Cruz 263), lo que nos lleva a concluir que este poema es el subtexto del "Canto".

Se nota en la poesía de la Madre Maria José una tendencia general a la exaltación en forma de panegíricos de figuras religiosas, o de la espiritualidad como valor absoluto. Sus poemas entonces se sobrecargan de manierismos laudatorios, lo que contribuye en gran medida a su ilegibilidad para un público secular. Así, a pesar de que sus escritos poseen evidente fuerza poética, musicalidad y belleza, su nombre continúa ausente en antologías o estudios críticos. Su virtual olvido se puede explicar como función del exceso de religiosidad en su poesía o como resultado de su propio esfuerzo en permanecer anónima. Su mensaje, tras haber sido transmitido a las monjas a quienes se dirigía, dejó de circular a falta de poseer otros valores que no fueran su mera utilización programática a nivel religioso. 
La religiosa brasileña escribió sobre todo motivada por un fuerte sentido de misión - la de finalizar el proyecto de implantación en Brasil de la orden carmelita y con ello vincular el convento de Santa Teresa en Río a su base histórica en España (Sciadini 667). Paradójicamente, su poesía "centrada en Cristo," como observó Bandeira, termina por constituirse en una suerte de zona de exclusión. Su algo fanática exposición de la fe se evidencia en el soneto "Louco de amor." En él, la Madre Maria José reactiva la clásica doctrina erasmiana -igualmente reavivada por Santa Teresa y por la teología de la contrarreforma - según la cual el cristianismo puro se percibe como locura desde la perspectiva secular. La poeta entonces intensifica el ideario del teólogo holandés a través de apóstrofes suplicatorios y en exagerado tono de anhelo: "Dá-me a tua loucura, ó meu louco, ó meu Deus" (Sonetos 19).

También en el himno anteriormente mencionado, "Na festa de nossa Santa Madre Teresa", la Madre Maria José recalca las nociones teresianas de la "vida como guerra" y, particularmente, de la vida monástica como batalla contra el mundo. En el cuarteto que sigue describe, con imágenes de clara connotación militarista, los propósitos sublimes de la vida conventual:

Os nossos muros são trincheiras

Os nossos Hábitos, bróqueis

As Carmelitas são guerreiras

Que a Jesus rendem os infiéis.

(Festas do Carmelo 85)

Como ya afirmamos previamente, en la poesía de la Madre Maria José, Santa Teresa representa tanto la esencia de lo sagrado como el modelo a ser imitado. El valor suplementario que la monja española adquiere en la obra de su continuadora americana, refleja aún otro principio teresiano, el de la diferenciación absoluta entre los religiosos y los santos. Santa Teresa, en su autobiografia, establece dos distintas actitudes devocionales - imitación y contemplación-según las cuales sus religiosas se deben comparar con figuras ejemplares del cristianismo. En su poesía, la Madre Maria José restaura tal esquema jerárquico al presentar a Santa Teresa alternativamente como modelo a imitarse o como objeto máximo de la contemplación. Cuando la escritora brasileña dramatiza el episodio de la transverberación resalta la simbología de la batalla sagrada. Tal escena adquiere entonces rasgos de evento casi mitológico.

Tras haber escrito, algunos años antes, "Na festa de nossa Santa Madre Teresa" poema en el cual la transverberación, aunque figura como elemento clave, es sólo uno entre otros eventos de la hagiología teresiana - la Madre Maria José compuso otra canción en forma de paráfrasis poética exclusivamente en torno al famoso episodio. El poema, titulado "Transverberação" (63-5), es enteramente fiel a la descripción que Santa Teresa hace de esta escena en La vida. En el poema, la santa recibe atributos hiperbólicos y heroicos que la definen como "sagrada amante", y que se asemeja a "um fogo ardente, quase agonizante de gozo e amor". Desde el punto de vista retórico, la 
composición sigue en general un orden bastante esquemático, valiéndose del discurso indirecto libre como elemento estructural dominante. Pero sus versos finales resultan más elaborados. En ellos, al abandonar la forma discursiva en favor de tonos vocativos más densos, la poeta sigue la técnica parnasiana de cierre lírico centrada en conclusiones grandiosas, a la vez que la voz suplicatoria del narrador comunica su deseo de imitar o igualarse a la figura central del poema. Al fin del texto se invierte también el rol de Santa Teresa en la escena. En vez de la trágica figura que se deja herir por un ángel, la santa se convierte en la que tiene el poder de herir a su discípula americana. Por consiguiente, se altera la leyenda de Santa Teresa, cambiándose su función pasiva a la de potencial agente del orden de lo sagrado.

\section{Ó Mãe, por tua bendita Transverberação, A esta filha Carmelita}

Fere o coração.

Como puro objeto de contemplación, Santa Teresa alcanza en su poesía una posición equivalente a la de Cristo y se circunscribe a ambos en un núcleo de estricta interrelación. En el soneto "Visão de Nossa Santa Madre Teresa de Jesus", la poeta produce una versión de otra famosa visión en que Santa Teresa sorprende a un niño en el claustro y lo reprende con vigor:

Quem és tu, que violaste a clausura sagrada?

-E tú quem és? - pergunta o infante com firmeza.

'Teresa de Jesus', torna a monja admirada.

-Pois eu, o infante diz, sou Jesus de Teresa.

(Sonetos 18)

En el terceto final, el modo retórico circular - que se obtiene con el uso del caso posesivo simultáneamente aplicado a Jesús y a Teresa - reemplaza la jerarquía entre Dios y la santa, estableciendo entre ambos un nexo a la vez inextricable y transitivo. Solamente que, en el proceso de aproximación de Teresa y Jesús se pierde la voz misma de la Madre Maria José, la cual, a fuerza de su obsesión por exaltar a los sujetos trascendentes de su poesía, parece desaparecer.

Los pocos críticos brasileños actuales en enterarse de la obra literaria de la Madre Maria José prefirieron no plantear el tema del desaparecimiento de su voz lírica, o de examinar el peso extraordinario de la figura de Santa Teresa en su poesía, hecho que seguramente contribuyó para silenciar su propia voz. Tal vez a causa de que hay un proceso pendiente de canonización suya, los que escribieron sobre ella se fijaron sobre todo en aspectos de su obra que resaltan su piadosa y optimista imagen de monja.

Al final de su vida, acometida de profundo agotamiento y duda - temas magistralmente planteados por Santa Teresa en La vida-Maria José registró en algunos 
apuntes detalles sobre una crisis espiritual que estaba viviendo, pero a su letra ya no se la podía descifrar. Irónicamente, al contrario de su precursora, cuyo renombre deriva en gran parte de los relatos que hizo de sus conflictos religiosos, la Madre Maria José - siguiendo al fin de su vida, quizás sin quererlo, el precepto carmelita de la sumisión- contribuyó a que su nombre se borrara de la historia literaria brasileña reciente, al dejar ilegible la narración de su crisis espiritual.

\section{OBRAS CITADAS}

Algranti, Leila M. Honradas e devotas: mulheres da Colônia. Río de Janeiro: José Olympio, 1993.

Bandeira, Manuel. "Prefacio". Maria José de Jesus. Sonetos e poemas. Río de Janeiro: Convento de Santa Teresa, 1960. 11-14. Obra completa. Río de Janeiro: Aguilar, 1967. Andorinha, andorinha. Coord. Carlos Drummond de Andrade. Río de Janeiro: José Olympio, 1986.

Benjamin, Walter. "The Task of the Translator". Theories of Translation. Rainer Schulte y John Biguenet (eds.). Chicago: University of Chicago Press, 1992. 7182.

Cruz, San Juan de la. Poesías. Domingo Ynduráin, ed. Madrid: Cátedra, 1987.

Delumeau, Jean. Sin and Fear: The Emergence of a Western Guilt Culture. Trad. Eric Nicholson. Nueva York: St. Martin's Press, 1990.

Leclercq, Jean. The Love of Learning and the Desire for God. Trad. Catharine Misrahi. Nueva York: Fordham University Press, 1961.

Jesus, Maria José de. Sonetos e poemas. Río de Janeiro: Convento de Santa Teresa, 1960.

Festas do Carmelo. Río de Janeiro: Convento de Santa Teresa, 1966. Vôo para Deus. São Paulo: Loyola, 1989.

Peers, Edgar Allison. Studies of the Spanish Mystics. Londres: Macmillan, 1951. Robinson-Valéry, Judith. "To Go to the Last Point": A la recherche d'une nouvelle définition du mysticisme". Paul Valéry: Musique, Mystique, Mathématique. Gifford y Stimpson, eds. Lille: Presses Universitaires de Lille, 1993. 15-36.

Romano, Roberto. Brasil: Igreja contra Estado. São Paulo: Caras, 1979. 102-139. Sciadini, Patrício. A liberdade atrás das grades. São Paulo: Loyola, 1989.

Teresa de Avila. La poesía de Santa Teresa. Angel Custodio Vega, ed. Madrid: Biblioteca de Autores Cristianos, 1972. La vida. Antonio Comas, ed. Barcelona: Planeta, 1984.

Valéry, Paul. The Art of Poetry. Trans. Denise Folliot. Nueva York: Vintage, 1961. 184-192, 279-294.

Cahiers. Judith Robinson, ed. 2 vols. París: Gallimard, 1973-74. 
Weber, Max. "Religious Rejections of the World and their Directions". From Max Weber. Ed. y trad. de H. H. Gerth y C. Wright Mills. Nueva York: Galaxy, 1958. 323-359. 1964.

The Sociology of Religion. Trad. de Ephraim Fischoff. Boston: Beacon Press, William, James. The Varieties of Religious Experience. Nueva York: Penguin, 1982. 